American Journal of Environmental Sciences 5 (1): 69-79, 2009

ISSN 1553-345X

(C) 2009 Science Publications

\title{
Modeling of Activated Sludge Floc Characteristics
}

\author{
${ }^{1}$ Ibrahim H. Mustafa, ${ }^{2}$ G.Ibrahim, ${ }^{1}$ Ali Elkamel and ${ }^{3}$ A.H. Elahwany \\ ${ }^{1}$ Department of Chemical Engineering, Waterloo University, ON, Canada (N2L3G1) \\ ${ }^{2}$ Basic Engineering Science Department, Menofia University, Faculty of \\ Engineering Shebin, El Kom, Egypt \\ ${ }^{3}$ Department of Chemical Engineering, Cairo University, Egypt
}

\begin{abstract}
Problem Statement: The activated sludge system needs to improve the operational performance and to achieve more effective control. To realize this, a better quantitative understanding of the biofloc characteristics is required. The objectives of this study were to: (i) Study the biofloc characteristics from kinetics-mass transfer interaction point of view by quantification of the weight of the aerobic portion of the activated sludge floc to the total floc weight. (ii) Study the effect of bulk concentrations of oxygen and nitrates, power input and substrates diffusivity on the portion aerobic portion of the floc. Approach: An appropriate mathematical model based on heterogeneous modeling is developed for activated sludge flocs. The model was taking into account three growth processes: Carbon oxidation, nitrification and de-nitrification in terms of four components: substrate, nitrate, ammonia, and oxygen. The model accounts for the internal and external mass transfer limitations and relates the external mass transfer resistance with power input. The floc model equations were twopoint boundary value differential equations. Therefore a central finite difference method is employed. Results: The percentage aerobic portion increased with increasing with oxygen bulk concentrations and power input and decreases when the bulk concentration of ammonia and substrate increases. Both will compete to consume the internal oxygen by autotrophic and heterotrophic bacteria through aerobic growth processes. The biofloc activity through the profiles was either totally active or partially active. The totally active biofloc is either totally aerobic or aerobic and anoxic together. Conclusions: The heterogeneous floc model was able to describe the biofloc characteristics and reflects the real phenomena existing in the activated sludge processes.
\end{abstract}

Key words: Activated sludge, flocs, nitrification, denitrification, bioflocs, aerobic, carbon oxidation

\section{INTRODUCTION}

The activated sludge process is a popular and versatile method of treating wastewater that uses biological reactions to convert waste into a microbial mass. The biomass is called activated sludge that consists of flocs made up of bacteria and organic and inorganic material. The formation of these flocs is important for the overall performance of the wastewater treatment process.

The activated sludge system needs to improve the operational performance and to achieve more effective control. To realize this, a better quantitative understanding of the biofloc characteristics is required. One way to achieve this is to make a more comprehensive model.

An activated sludge process basically consists of two operating units: An aerobic basin and a secondary clarifier. The reactions taking place in the aeration basin involve both bulk liquid phase and microbial floc phase. Metabolic reactions occur simultaneously with mass transfer within the floc matrix. So that a concentration gradient is established inside the floc which may affect the reaction rates in the system ${ }^{[1]}$.

The nature of the interactions inside the flocs can be explained. The oxygen hardly diffuses at all into the interior of the flocs, but is consumed only by those bacteria situated on the floc surfaces or freely suspended in the liquid ${ }^{[2]}$. It follows that the entire region of the flocs almost be oxygen- free and the bacteria situated there must be either inactive or undergoing some form of anaerobic metabolism.

This study aims to evaluate quantitatively one of the major characteristics of the activated sludge floc that is the weight of the aerobic portion of the floc to the total floc weight. This is achieved through a more comprehensive floc model which treats microbial flocs

Corresponding Author: Ali Elkamel, Department of Chemical Engineering, Waterloo University, On. Canada (N2L3G1) 
and liquid existing as separate phases in the system and mass transfer limitations within the flocs is considered.

A substantial amount of research has been conducted on modeling of the activated sludge process with attention focused on modeling the carbonaceous oxidation, the nitrification- denitrification and the dissolved oxygen dynamics ${ }^{[3-6]}$.

All of the above sludge models are based on homogenous modeling. They assumed that the microbial flocs present in the aeration basin and the liquid phase surrounding the flocs were in a single phase system. The activated sludge kinetic model proposed by the IAWPRC task group ${ }^{[4]}$ was also based on this assumption. In reality, the intraparticle diffusion limitations within activated sludge flocs may be of significance in practical situations ${ }^{[7]}$. Research attention has recently focused on mass transfer within flocs of the activated sludge process ${ }^{[8-10]}$. Benefield and $\mathrm{Mol}^{[9,}$ ${ }^{11]}$ proposed a distributed parameter model that included the material balance equations with Monod-type kinetics for the substrates inside the flocs and assumed an average floc size instead of considering the floc size distribution in the system in order to account for the effect of flocs on the dynamics of the system. Beccari et $a l .^{[12]}$ developed a simple floc model that emphasized the nitrification process in suspended culture and that took into account the resistance related to oxygen diffusion inside the biofloc.

Tyagi et al. ${ }^{[1]}$ developed a simple floc model that took into account two growth processes: carbonaceous oxidation and nitrification which were interacting through their competition for dissolved oxygen inside the floc. Their model did not incorporate the anoxic decomposition. In addition, the aerobic portion was assumed to $100 \%$ weight of the total floc. The model also neglected the external mass transfer resistance due to boundary layer.

\section{MATERIALS AND METHODS}

Biofloc model development: The key to successful modeling of the activated sludge process is to make the appropriate assumptions to achieve a compromise between complexity and utility. The main attention of this study was given to the modeling of the bioreaction taking place in the reaction basin. The kinetic model structure and parameters were taken in this study to represent the basic kinetic model IAWPRC of Henze, et $a t .{ }^{[4]}$. The model considers the biofloc in the aeration basin and the liquid surrounding them as a single-phase system. In fact, however, two separate phases are involved $^{[5]}$ and the effects caused by the presence of floc and liquid phases on the dynamics of activated sludge processes may be significant ${ }^{[1,9,11,19]}$ Thus, in this study, a floc model was developed to describe the basic reactions taking place in the aeration basin. Three-growth processes (carbonaceous oxidation, nitrification) and denitrification in terms of four main components (substrate, ammonia, nitrate and oxygen) are considered In addition power input and substrate diffusivities were taken into consideration.

The assumptions made in this study, include:

- Spherical flocs.

- The environmental conditions such as temperature and $\mathrm{pH}$ are constant ${ }^{[13]}$.

- Uniform density of the biomass and constant density of heterotrophs and autotrophs in flocs ${ }^{[1]}$.

- External mass transfer resistance due to boundary layer is considered.

- Average floc size is assumed to be constant instead of considering the floc size distribution in the system. ${ }^{[9,11]}$

- $\quad$ Liquid phase is assumed to be mixed completely to keep the oxygen concentration DO constant in each zone in the reactor.

Derivation of the biofloc model: The reactions within the floc matrix were assumed to follow the IAWPRC kinetic model of Henze, et al. ${ }^{[4]}$. A differential shell of a spherical floc is shown in Fig. 1. In figure the diffusional resistance of dissolved oxygen $(\mathrm{C})$, readily biodegradable substrate $(\mathrm{S})$, nitrate nitrogen $(\mathrm{Z})$ and ammonia- nitrogen $(\mathrm{H})$ inside the floc respectively. The differential equations will be considered in the dimensionless form to reduce the number of parameters, to simplify the solution technique and to be able to perform the appropriate comparison between several models and also for the ease of scale-up of the processes.

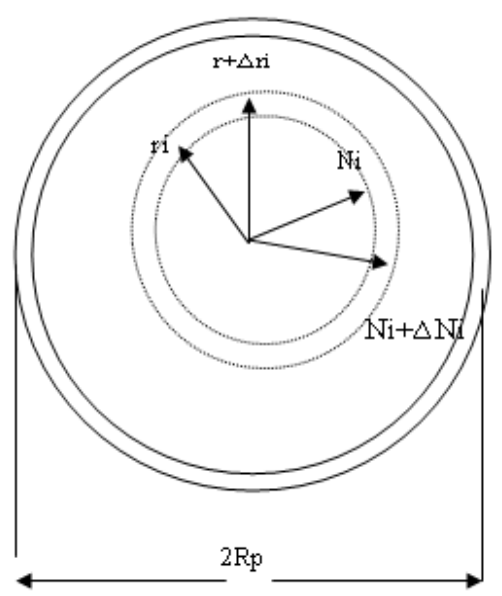

Fig. 1: Floc model 
Where:

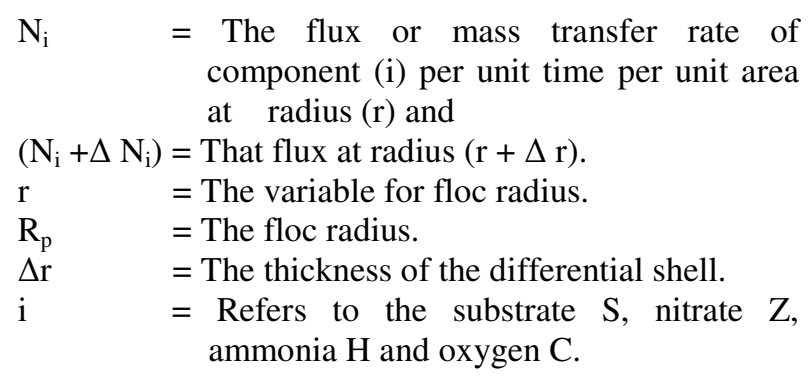

Steady state substrate $(s)$ mass balance: Applying a component mass balance on the substrate through a differential element $\Delta \mathrm{r}$ gives

$$
\mathrm{N}_{\mathrm{s}} \mathrm{A}_{\mathrm{r}=}\left(\mathrm{N}_{\mathrm{s}}+\square \mathrm{N}_{\mathrm{s}}\right) \mathrm{A}_{\mathrm{r}}+\square \mathrm{R}_{\mathrm{s}}\left(\rho 4 \pi \mathrm{r}^{2} \square \mathrm{r}\right)
$$

Where:

$\mathrm{N}_{\mathrm{s}} \quad=$ The flux or mass of substrate transported per unit time per unit area at radius ( $\mathrm{r}$ )

$\mathrm{N}_{\mathrm{s}}+\Delta \mathrm{N}_{\mathrm{s}}=$ The flux or mass of substrate transported per unit time per unit area at radius $(\mathrm{r}+\Delta$ r).

$\mathrm{A}_{\mathrm{r}} \quad=$ The surface area of the floc of a radius ( $\mathrm{r}$ ).

$\mathrm{A}_{\mathrm{r}+\Delta \mathrm{r}} \quad=$ The surface area of the floc of a radius $(\mathrm{r}+$ $\Delta \mathrm{r}$ ).

Rs = The process rate of substrate Substituting

For $A_{r}=4 \Pi r^{2}$ and $A_{r+\Delta r}=4 \Pi(r+\Delta r)^{2}$ we get:

$\mathrm{N}_{\mathrm{s}}\left(4 \pi \mathrm{r}^{2}\right)=\left(\mathrm{N}_{\mathrm{s}}+\Delta \mathrm{N}_{\mathrm{s}}\right)(4 \pi)(\mathrm{r}+\Delta \mathrm{r})^{2}+\mathrm{R}_{\mathrm{s}}\left(\rho 4 \pi \mathrm{r}^{2} \Delta \mathrm{r}\right)$

$\mathrm{r}^{2} \frac{\Delta \mathrm{N}_{\mathrm{s}}}{\Delta \mathrm{r}}+2 \mathrm{rN}_{\mathrm{s}}+\rho \mathrm{r}^{2} \mathrm{R}_{\mathrm{s}}=0$

Since

$$
\lim _{\Delta \mathrm{r} \rightarrow 0}\left(\frac{\Delta \mathrm{N}_{\mathrm{S}}}{\Delta \mathrm{r}}\right)=\frac{\mathrm{dN}_{\mathrm{S}}}{\mathrm{dr}}
$$

Then,

$\mathrm{r}^{2} \frac{\mathrm{dN}_{\mathrm{S}}}{\mathrm{dr}}+2 \mathrm{rN} \mathrm{s}_{\mathrm{s}}+\rho \mathrm{r}^{2} \mathrm{R}_{\mathrm{S}}=0$

But Ficks' law of diffusion is:

$$
\mathrm{N}_{\mathrm{s}}=-\mathrm{D}_{\mathrm{s}} \frac{\mathrm{ds}}{\mathrm{dr}}
$$

Or

$\frac{\mathrm{dN}_{\mathrm{S}}}{\mathrm{dr}}=-\mathrm{D}_{\mathrm{S}} \frac{\mathrm{d}^{2} \mathrm{~S}}{\mathrm{dr}^{2}}$

Where $D_{S}$ is the substrate diffusivity coefficient and substituting in Eq. 5 gives:

$$
-r^{2} D_{s} \frac{d^{2} s}{d r^{2}}-2 r D_{s} \frac{d s}{d r}+\rho r^{2} R_{s}=0
$$

Equation 8 can be reduced to:

$$
\frac{\mathrm{d}^{2} \mathrm{~s}}{\mathrm{dr}^{2}}+\frac{2}{\mathrm{r}} \frac{\mathrm{ds}}{\mathrm{dr}}=\frac{\rho}{\mathrm{D}_{\mathrm{S}}} \mathrm{R}_{\mathrm{S}}
$$

With the boundary conditions

$$
\begin{aligned}
& \text { at } r=0 \quad \frac{\mathrm{ds}}{\mathrm{dr}}=0 \quad \text { at } \mathrm{r}=\mathrm{R}_{\mathrm{p}} \\
& \therefore-\left.\mathrm{D}_{\mathrm{s}} \frac{\mathrm{ds}}{\mathrm{dr}}\right|_{\mathrm{r}=\mathrm{Rp}}=\mathrm{Kg}_{\mathrm{s}}\left[\mathrm{s}_{\mathrm{b}}-\mathrm{s}_{\mathrm{s}}\right]
\end{aligned}
$$

$\mathrm{Kg}_{\mathrm{s}}$ is the mass transfer coefficient of substrate, $\mathrm{s}_{\mathrm{b}}$ is the bulk concentration and $\mathrm{s}_{\mathrm{s}}$ is the surface concentration in $\mathrm{mgl}^{-1}$ Transformation of the equation into dimensionless form using the following two dimensionless variables:

$$
\begin{gathered}
\mathrm{W}=\frac{\mathrm{r}}{\mathrm{R}_{\mathrm{p}}}, \quad \mathrm{S}=\frac{\mathrm{s}\left(\mathrm{mg}^{-1}\right)}{\mathrm{K}_{\mathrm{s}}\left(\mathrm{mg}^{-1}\right)} \\
\mathrm{R}_{\mathrm{s}}=\frac{\mu_{\mathrm{H}} \mathrm{SC}\left(1 / \mathrm{Y}_{\mathrm{H}}\right)}{(\mathrm{S}+1)(\mathrm{C}+1)}+\frac{\eta_{\mathrm{H}} \mu_{\mathrm{H}} \mathrm{SZ}\left(1 / \mathrm{Y}_{\mathrm{H}}\right)}{(\mathrm{S}+1)(\mathrm{C}+1)(\mathrm{Z}+1)}
\end{gathered}
$$

$\frac{\mathrm{d}^{2} \mathrm{~s}}{\mathrm{dw}^{2}}+\frac{2}{\mathrm{w}} \frac{\mathrm{ds}}{\mathrm{dw}}=\frac{\Phi_{1} \mathrm{sc}}{(\mathrm{S}+1) \mathrm{C}+1)}+\frac{\Phi_{2} \mathrm{sz}}{(\mathrm{S}+1) \mathrm{C}+1)(\mathrm{Z}+1)}$

Subject to the following B.Cs

$$
\left.\frac{\mathrm{ds}}{\mathrm{dw}}\right|_{\mathrm{w} \rightarrow 0}=0,\left.\quad \frac{\mathrm{ds}}{\mathrm{dw}}\right|_{\mathrm{w}-1}-\mathrm{sh}_{\mathrm{s}}\left(\mathrm{s}_{\mathrm{b}}-\mathrm{s}_{\mathrm{c}}\right)
$$

Where:
$\Phi_{1}=\frac{\rho \mathrm{R}_{\mathrm{p}}^{2} \mu \mathrm{H} \eta \mathrm{g}}{\mathrm{D}_{\mathrm{s}} \mathrm{K}_{\mathrm{s}} \mathrm{Y}_{\mathrm{H}}}$,
$\Phi_{2}=\frac{\rho R_{\mathrm{p}}^{2} \mu_{\mathrm{H}} \eta_{\mathrm{g}}}{D_{\mathrm{s}} K_{\mathrm{s}} Y_{\mathrm{H}}}$ and 
Am. J. Environ. Sci., 5 (1): 69-79, 2009

$\mathrm{Sh}_{\mathrm{s}}=\frac{\mathrm{K}_{\mathrm{g}} \mathrm{sR}}{\mathrm{D}_{\mathrm{s}}}$

Steady state nitrate (z) mass balance: Applying a component mass balance on the nitrate through a differential element $\Delta \mathrm{r}$ gives

$\frac{\mathrm{d}^{2} \mathrm{Z}}{\mathrm{dw}^{2}}+\frac{2}{\mathrm{w}} \frac{\mathrm{dZ}}{\mathrm{dw}}=\frac{\Phi 4 \mathrm{HC}}{(\mathrm{H}+1)(\mathrm{C}+\alpha)}+\frac{\Phi 3 \mathrm{SZ}}{(\mathrm{S}+1)(\mathrm{C}+1)(\mathrm{Z}+1)}$

Boundary conditions:

$$
\begin{aligned}
& \left.\frac{\mathrm{dZ}}{\mathrm{dw}}\right|_{\mathrm{w} \rightarrow 0}=0 \\
& \frac{\mathrm{dZ}}{\mathrm{dw}} \mid \mathrm{W}=1^{=\mathrm{Sh}_{\mathrm{z}}\left(\mathrm{Z}_{\mathrm{b}}-\mathrm{Z}_{\mathrm{s}}\right)}
\end{aligned}
$$

Where

$$
\begin{aligned}
& \Phi_{3}=\frac{\rho R^{2} p \mu_{H}\left(1-Y_{H}\right)}{2.86 D_{Z} K_{Z} Y_{H}}, \Phi_{4}=\frac{-\rho R_{p}^{2} \mu_{\mathrm{A}}}{D_{\mathrm{Z}} \mathrm{K}_{\mathrm{Z}} \mathrm{Y}_{\mathrm{H}}}, \\
& \mathrm{sh}_{\mathrm{Z}}=\frac{\mathrm{K}_{\mathrm{gZ}} \mathrm{R}_{\mathrm{P}}}{\mathrm{D}_{\mathrm{Z}}}, \quad \alpha=\frac{\mathrm{K}_{\mathrm{CA}}}{\mathrm{K}_{\mathrm{CH}}}
\end{aligned}
$$

Steady state ammonia (H) mass balance: Applying a component mass balance on the ammonia through a differential element $\Delta \mathrm{r}$ gives

$$
\frac{\mathrm{d}^{2} \mathrm{H}}{\mathrm{dw}^{2}}+\frac{2}{\mathrm{w}} \frac{\mathrm{dH}}{\mathrm{dw}}=\frac{\Phi_{5} \mathrm{HC}}{(\mathrm{H}+1)(\mathrm{C}+\alpha)}
$$

Boundary conditions:

$$
\left.\frac{\mathrm{dH}}{\mathrm{dw}}\right|_{\mathrm{w} \rightarrow 0}=0,\left.\frac{\mathrm{dH}}{\mathrm{dw}}\right|_{\mathrm{w}=1}=\operatorname{sh}_{\mathrm{h}}\left(\mathrm{H}_{\mathrm{b}}-\mathrm{H}_{\mathrm{s}}\right)
$$

Where:

$$
\Phi_{5}=\frac{\rho R_{\mathrm{p}}^{2} \mu_{\mathrm{A}}}{\mathrm{D}_{\mathrm{h}} \mathrm{K}_{\mathrm{h}} \mathrm{Y}_{\mathrm{A}}}, \quad \mathrm{Sh}_{\mathrm{h}}=\frac{\mathrm{K}_{\mathrm{gh}} \mathrm{R}_{\mathrm{p}}}{\mathrm{D}_{\mathrm{h}}}
$$

Steady state oxygen (c) mass balance: Applying a component mass balance on the oxygen through a differential element $\Delta \mathrm{r}$ gives

$$
\frac{\mathrm{d}^{2} \mathrm{C}}{\mathrm{dw} 2}+\frac{2 \mathrm{dC}}{\mathrm{wdw}}=\frac{\Phi_{6} \mathrm{SC}}{(\mathrm{S}+1)(\mathrm{C}+1)}+\frac{\Phi_{7} \mathrm{HC}}{(\mathrm{H}+1)(\mathrm{C}+\alpha)}
$$

Boundary conditions:
$\left.\frac{\mathrm{dC}}{\mathrm{dw}}\right|_{\mathrm{w} \rightarrow 0}=0,\left.\frac{\mathrm{dc}}{\mathrm{dw}}\right|_{\mathrm{w}=1}=\operatorname{Sh}_{\mathrm{c}}\left(\mathrm{C}_{\mathrm{b}}-\mathrm{C}_{\mathrm{s}}\right)$

Where

$$
\begin{aligned}
& \Phi_{6}=\left(\frac{1-\mathrm{Y}_{\mathrm{H}}}{\mathrm{Y}_{\mathrm{H}}}\right) \frac{\rho \mathrm{R}_{\mathrm{p}}^{2} \mu_{\mathrm{H}}}{\mathrm{D}_{\mathrm{c}} \mathrm{K}_{\mathrm{c}}} \\
& \Phi_{7}=\left(\frac{4.57-\mathrm{Y}_{\mathrm{A}}}{\mathrm{Y}_{\mathrm{A}}}\right) \frac{\rho \mathrm{R}_{\mathrm{p}}^{2} \mu_{\mathrm{A}}}{\mathrm{D}_{\mathrm{C}} \mathrm{K}_{\mathrm{C}}} \text {, and } \mathrm{sh}_{\mathrm{c}}=\frac{\mathrm{K}_{\mathrm{gc}} \mathrm{R}_{\mathrm{p}}}{\mathrm{D}_{\mathrm{c}}}
\end{aligned}
$$

$\mathrm{S}, \mathrm{Z}, \mathrm{H}$ and $\mathrm{C}$ are dimensional concentrations of substrate, nitrate, ammonia and oxygen respectively.

$\mathrm{Sh}_{\mathrm{s}}, \mathrm{Sh}_{\mathrm{z}}, \mathrm{Sh}_{\mathrm{h}}$ and $\mathrm{Sh}_{\mathrm{c}}$ are Sherwood numbers of substrate, nitrate, ammonia and oxygen respectively.

$\mathrm{S}_{\mathrm{b}}, \mathrm{Z}_{\mathrm{b}}, \mathrm{H}_{\mathrm{b}}$ and $\mathrm{C}_{\mathrm{b}}$ are bulk concentrations of substrate, nitrate, ammonia and oxygen respectively.

$\mathrm{S}_{\mathrm{s}}, \mathrm{Z}_{\mathrm{s}}, \mathrm{H}_{\mathrm{s}}$ and $\mathrm{C}_{\mathrm{s}}$ are surface concentrations of substrate, nitrate, ammonia and oxygen respectively.

$R_{s}, R_{z}, R_{h}$ and $R_{c}$ reaction rates associated with floc matrix as defined by Henze, et al. ${ }^{[4]}$ and $\alpha$ is the ratio between $\mathrm{K}_{\mathrm{CA}}$ and $\mathrm{K}_{\mathrm{CH}}$.

Model parameters: Tables 1, 2 and 3 give the average

\begin{tabular}{|c|c|c|c|}
\hline Symbol & Units & Value & Ref. \\
\hline$\mu_{\mathrm{A}}$ & $\begin{array}{l}\text { Max. specific growth rate } \\
\text { for autotrophic biomass }\left(\text { day }^{-1}\right)\end{array}$ & 1 & Henze, M. et al. ${ }^{[4]}$ \\
\hline$\mu_{H}$ & $\begin{array}{l}\text { Max. specific growth rate for } \\
\text { heterotrophic biomass }\left(\text { day }^{-1}\right)\end{array}$ & 20 & Henze, M. et al ${ }^{[4]}$ \\
\hline$\eta_{g}$ & $\begin{array}{l}\text { Correction factor under } \\
\text { anoxic conditions } \\
\text { (dimensionless) }\end{array}$ & 0.85 & Henze, M. et al.$^{[4]}$ \\
\hline$\eta_{\mathrm{H}}$ & $\begin{array}{l}\text { Correction factor for } \\
\text { hydrolysis under anoxic } \\
\text { conditions (dimensionless) }\end{array}$ & 0.38 & Henze, M. et al.$^{[4]}$ \\
\hline $\mathrm{Y}_{\mathrm{A}}$ & $\begin{array}{l}\text { Yield for autotrophic biomass } \\
\text { (g cell COD formed } \mathrm{g}^{-1} \mathrm{~N} \\
\text { oxidized) }\end{array}$ & 0.65 & Henze, M. et al.$^{[4]}$ \\
\hline $\mathrm{Y}_{\mathrm{H}}$ & $\begin{array}{l}\text { Yield for heterotrophic } \\
\text { Biomass ( } \mathrm{g} \text { cell COD } \\
\text { Formed } \mathrm{g}^{-1} \text { COD oxidized) }\end{array}$ & 0.85 & Henze, M. et al.$^{[4]}$ \\
\hline
\end{tabular}
values of stoichiometric, kinetic, switching and rheological parameters at neutral $\mathrm{pH}$ and $20{ }^{0} \mathrm{C}$ for domestic wastewater. They are based on the IAWPRC task group by Henze et al. ${ }^{[4]}$ as a basic reference in addition to other references shown in the tables. Some parameter values are dependent on specific factors in the wastewater and on environmental conditions i.e. the power input is representative of not actual used plant.

Table 1: Stoichometric and kinetic parameter values 
Evaluation of mass transfer coefficients: It has been found that at high agitation intensities, turbulence is expected to affect mass transfer rate at the biofloc surface. In this case, the concept of local isotropic turbulence may be applied ${ }^{[14,15]}$. The isotropic turbulence Re-number, $\mathrm{Re}_{\mathrm{e}}$, for the floc particle diameter $\mathrm{d}$ is given by:

$$
\operatorname{Re}_{\mathrm{e}}=\frac{\mathrm{d}^{4 / 3} \rho^{2 / 3}(\mathrm{P} / \mathrm{V})^{1 / 3}}{\mu}
$$

Table 2: Saturation and switching functions

\begin{tabular}{|c|c|c|c|}
\hline Symbol & Units & Value & Ref. \\
\hline$\overline{\mathrm{K}_{\mathrm{CA}}}$ & $\begin{array}{l}\text { Oxygen half saturation } \\
\text { coefficient for autotrophic } \\
\text { biomass } \mathrm{mg} \mathrm{O}_{2} / 1\end{array}$ & 0.05 & Henze, M. et al. $^{[4]}$ \\
\hline $\mathrm{K}_{\mathrm{CH}}$ & $\begin{array}{l}\text { Oxygen half saturation } \\
\text { coefficient for heterotrophic } \\
\text { biomass } \mathrm{mg} \mathrm{O}_{2} / 1\end{array}$ & 0.05 & Henze, M. et al. ${ }^{[4]}$ \\
\hline $\mathrm{K}_{\mathrm{Z}}$ & $\begin{array}{l}\text { Nitrate half saturation } \\
\text { coefficient for denitrifying } \\
\text { heterotrophic biomass mg } \\
\mathrm{NO}_{3}-\mathrm{N} / 1\end{array}$ & 1 & Henze, M. et al. ${ }^{[4]}$ \\
\hline $\mathrm{K}_{\mathrm{H}}$ & $\begin{array}{l}\text { Ammonia half saturation } \\
\text { coefficient for autotrophic } \\
\text { biomass } m g \mathrm{NH}_{3}-\mathrm{N} / 1\end{array}$ & 1.5 & Henze, M. et al. ${ }^{[4]}$ \\
\hline \multirow[t]{2}{*}{ Ks } & $\begin{array}{l}\text { Half saturation coefficient } \\
\text { for heterotrophic biomass }\end{array}$ & 30 & Henze, M. et al. ${ }^{[4]}$ \\
\hline & $\mathrm{mg} \mathrm{COD} / 1$ & & \\
\hline
\end{tabular}

Table 3: Rheological properties parameters

\begin{tabular}{llll}
\hline Symbol & Units & Value & Ref. \\
\hline $\mathrm{D}_{\mathrm{S}}$ & Substrate diffusivity $\left(\mathrm{cm}^{2} / \mathrm{S}\right)$ & $1.00 \mathrm{E}-05$ & Atkinson, B. ${ }^{[13]}$ \\
$\mathrm{D}_{\mathrm{H}}$ & Ammonia diffusivity $\left(\mathrm{cm}^{2} / \mathrm{S}\right)$ & $1.86 \mathrm{E}-05$ & Henze, M. et al. ${ }^{[4]}$ \\
$\mathrm{D}_{\mathrm{Z}}$ & Nitrate diffusivity $\left(\mathrm{cm}^{2} / \mathrm{S}\right)$ & $162 . \mathrm{E} .-7$ & Henze, M. et al. ${ }^{[4]}$ \\
$\mathrm{D}_{\mathrm{C}}$ & Oxygen diffusivity $\left(\mathrm{cm}^{2} / \mathrm{S}\right)$ & $26 . \mathrm{E}-6$ & Henze, M. et al. ${ }^{[4]}$ \\
$\mathrm{P}$ & Wet density-dry wt./wet & 30 & Henze, M. et al. ${ }^{[4]}$ \\
& Biomass vol. $\left(\mathrm{gm}^{-1}\right)$ & & \\
$\mu$ & Viscosity $\left(\mathrm{gm} \mathrm{cm}^{-2} \cdot \mathrm{S}\right)$ & 0.01 & Henze, M. et al. ${ }^{[4]}$ \\
$\mathrm{P} / \mathrm{V}$ & Power input $\left(\mathrm{W} \mathrm{m}^{-3}\right)$ & 20 & Actual plant \\
$\mathrm{Rp}$ & Floc radius $(\mathrm{cm})$ & 0.05 & Actual plant \\
\hline
\end{tabular}

Moo Yoong and Blanch ${ }^{[15]}$ developed a correlation for rigid surface particle mass transfer in biochemical reactors in terms of the energy input to the system as follows:

$$
\mathrm{Sh}=0.13 \operatorname{Re}_{\mathrm{e}}^{3 / 4} \mathrm{Sc}^{1 / 3}
$$

Where:

$$
\begin{aligned}
& \mathrm{Sh}(\text { Sherwood number })=\frac{\text { total mass transfer }}{\text { diffusive mass transfer }}=\frac{\mathrm{K}_{1} \mathrm{~d}}{\mathrm{D}_{1}} \\
& \mathrm{Sc}(\text { Schmidt number })=\frac{\text { momentum diffusiv. }}{\text { diffusive mass transfer }}=\frac{\mu}{\rho \mathrm{D}_{1}}
\end{aligned}
$$

$\operatorname{Re}($ Reynolds number $)=\frac{\text { inertia forces }}{\text { viscous forces }}=\frac{\rho d v}{\mu}$

The mass transfer coefficient $\left(\mathrm{k}_{\mathrm{L}}\right)$ is seen to be dependent on $(\mathrm{P} / \mathrm{V})^{1 / 4}$ which can be expressed by the effect of power input on interfacial area ${ }^{[15]}$. These relations are used to calculate the mass transfer coefficients of the considered four components as a function of the power input.

Solution technique: The floc model equations describing the diffusional limitations inside the flocs are two- point boundary value differential equations. Therefore a central finite difference method was employed. In the floc model a large number of points are used inside this floc to give a better accuracy.

\section{RESULTS}

The weight of aerobic portion (zone) to the total floc, known as the percentage aerobic ratio, was studied as a function of the bulk liquid concentrations of the components: substrate, ammonia, oxygen, ammonia and nitrate, besides energy input and substrate diffusivities. Figure 2 shows the effect of floc size on the percentage aerobic ratio at the corresponding bulk concentrations. In Fig. 2, the floc is totally aerobic when its size is very small, where the percentage aerobic ratio is constant at $100 \%$ as shown in the horizontal line (AB). In the part (BC) the percentage aerobic ratio continuously decreases as the floc size increases

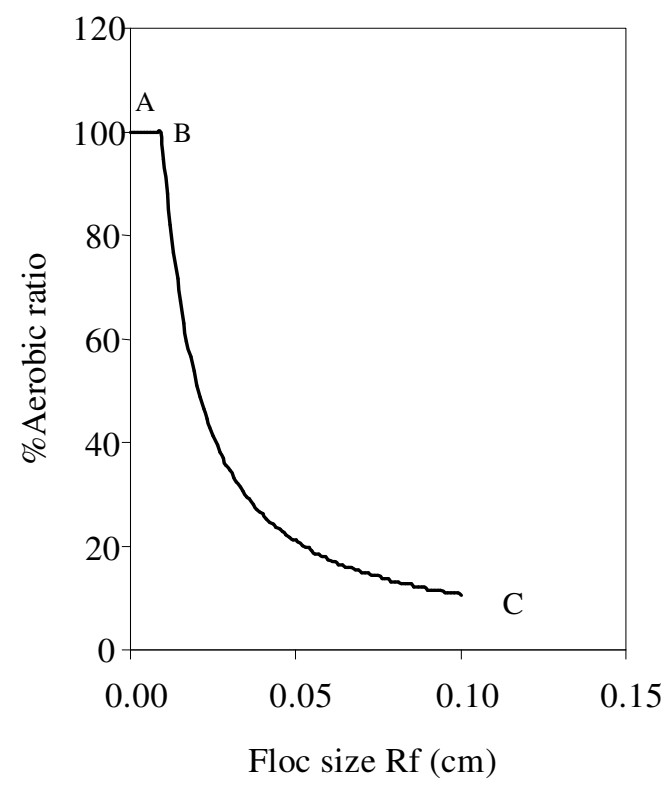

Fig. 2: Effect of the floc size on the $\%$ 
Am. J. Environ. Sci., 5 (1): 69-79, 2009

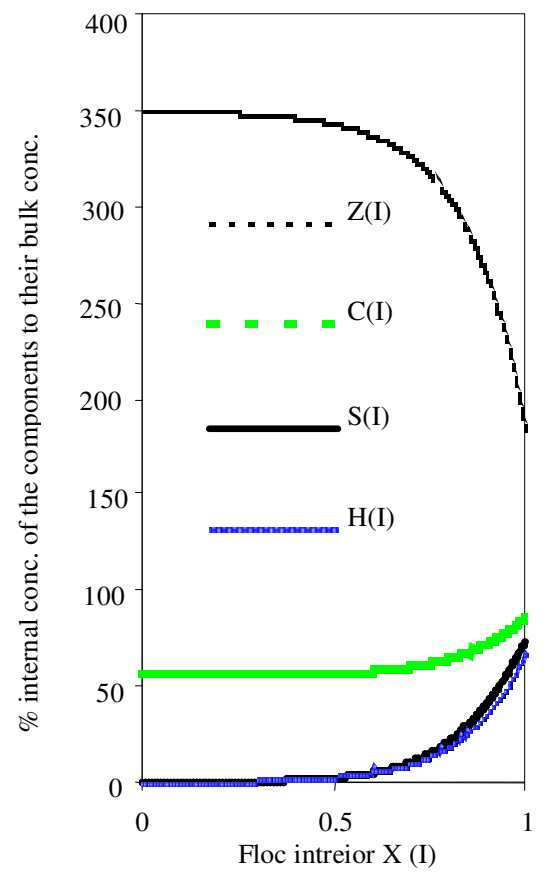

Fig. 3: Profiles of nitrates, ammonia, substrate and oxygen along the floc radius at $C_{b}=10, S_{b}=60$, $\mathrm{H}_{\mathrm{b}}=0.4$, and $\mathrm{Z}_{\mathrm{b}}=0.1 \mathrm{mg} \mathrm{l}^{-1}$

Figure 3 gives an example for biofloc profiles of totally active totally aerobic where the bulk concentration of oxygen is very high, so that its internal concentration was not completely consumed through the floc, where it decreases from $85 \%$ at the surface to $55 \%$ at the center. The nitrate profile shows that the internal nitrate is continuously produced through the floc, where its internal concentration increases from $183 \%$ at the surface to $350 \%$ at the center.

The substrate profile shows that the percentage internal concentration of substrate reduced from $73 \%$ at the surface to a very small value approaching zero at the center. The ammonia profile behaves nearly the same as the substrate profile, where there is no large difference between them.

Figure 4 gives an example for biofloc profiles of totally active but aerobic and anoxic, the aerobic portion represents $16 \%$ of the floc and the anoxic represents the rest. It is shown in the figure that the percent of the internal nitrate concentration to its bulk concentration increases from $113 \%$ at the floc surface to $119.1 \%$ at the limit of the aerobic portion. It is shown from the substrate and oxygen profiles that their internal concentrations decreased. In Fig. 4, it is shown that nitrate, in the anoxic zone, was reduced by the denitrifying bacteria until reaching the floc center where its internal concentration becomes $76 \%$ of the bulk concentration.

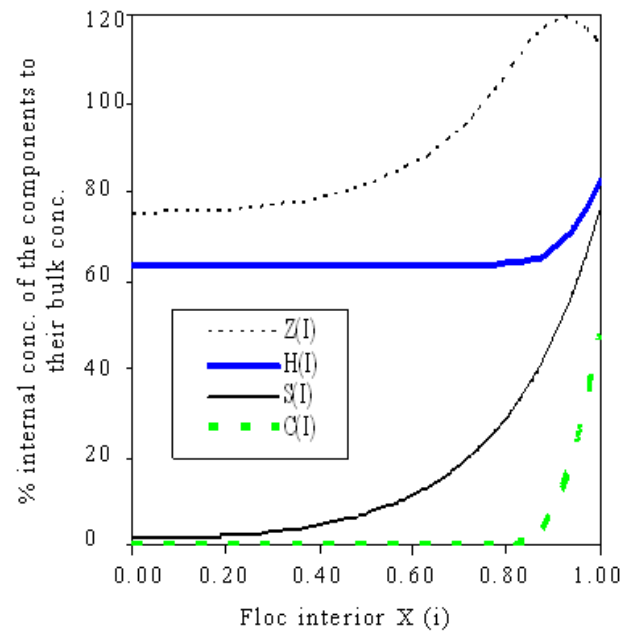

Fig. 4: Profiles of nitrate, ammonia, substrate and oxygen concentrations along the floc radius at $\mathrm{C}_{\mathrm{b}}=5, \mathrm{H}_{\mathrm{b}}=3, \mathrm{~S}_{\mathrm{b}}=75, \mathrm{Z}_{\mathrm{b}}=2.5 \mathrm{mg} \mathrm{l}^{-1}$

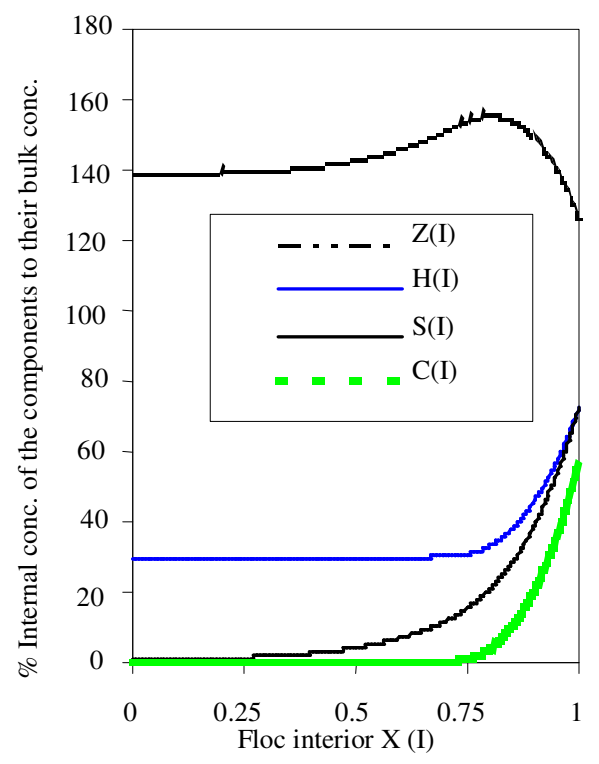

Fig. 5: Profiles of nitrate, ammonia, substrate, and oxygen concentrations at along the floc radius $\mathrm{S}_{\mathrm{b}}=45, \mathrm{Z}_{\mathrm{b}}=1.5, \mathrm{H}_{\mathrm{b}}=1.5$, and $\mathrm{C}_{\mathrm{b}}=5 \mathrm{mg} \mathrm{l}^{-1}$

In the ammonia profile the internal concentration decreases from $80 \%$ at the surface to $64 \%$ at the limit of the aerobic portion then becomes nearly constant through the anoxic zone until the floc center. The internal substrate concentration reduced through both aerobic and anoxic zones from $76.3 \%$ at the surface to $1 \%$ at the center. Figures 5 and 6 represent examples for the partially active biofloc. In Fig. 5, the active 
Am. J. Environ. Sci., 5 (1): 69-79, 2009

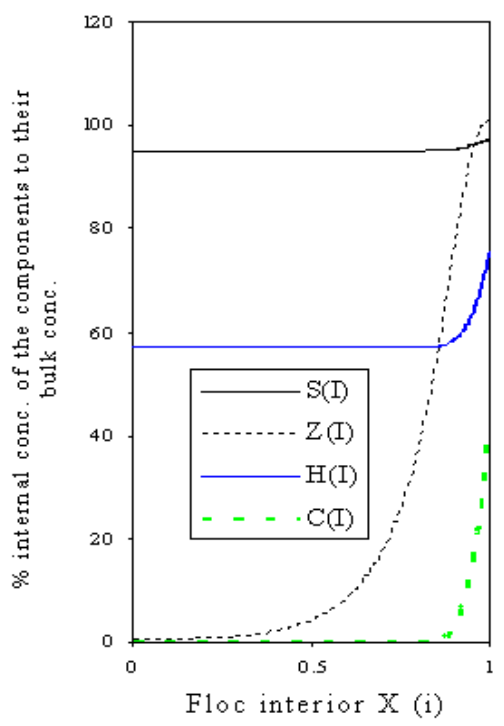

Fig. 6: Profiles of nitrate, ammonia, substrate, and oxygen at concentrations at along the floc radius $\mathrm{S}_{\mathrm{b}}=600, \mathrm{Z}_{\mathrm{b}}=0.1, \mathrm{H}_{\mathrm{b}}=0.15$, and $\mathrm{C}_{\mathrm{b}}=2 \mathrm{mg}$ $1^{-1}$

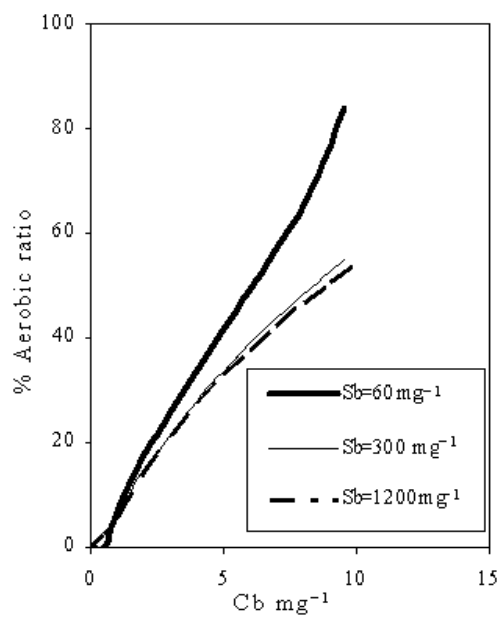

Fig. 7: Effect of $C_{b}$ on aerobic ratio at different $S_{b}$ values

portion of the floc represents $80 \%$ of the floc through the anoxic zone then nearly remains constant in the inactive portion It is shown that the percentage internal concentration of ammonia decreases from $72 \%$ at the surface to $31 \%$ at the limit of the aerobic zone, then it remains constant in the inactive portion. Figure 6 shows that the internal oxygen and nitrate were completely consumed before reaching the floc center. Ammonia concentration decreased from $75.2 \%$ at the surface to $56.7 \%$ at the center of the floc then remains constant.

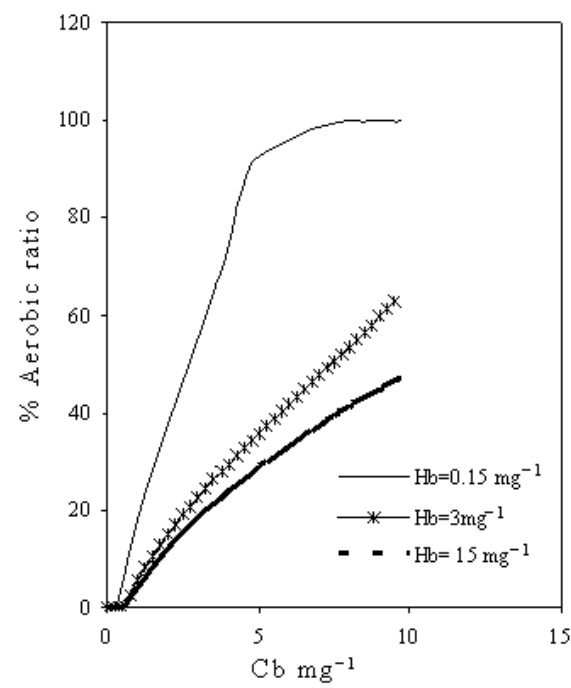

Fig. 8: Effect of $C_{b}$ on aerobic ratio at different $H_{b}$ values

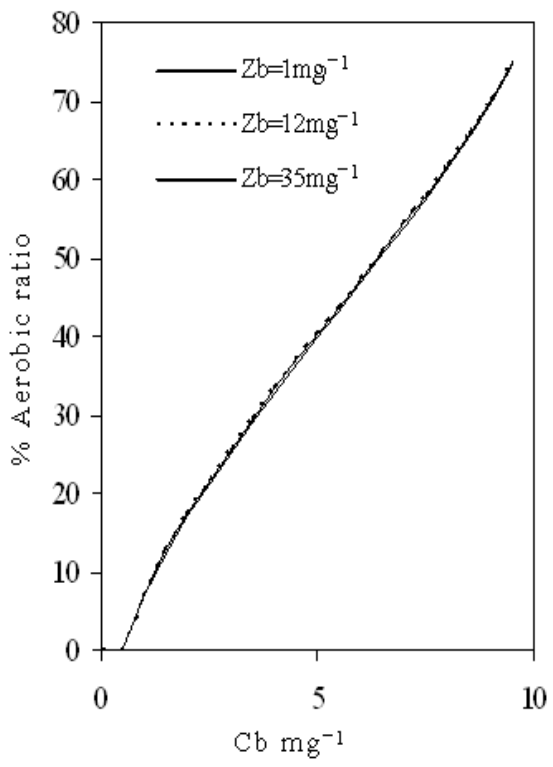

Fig. 9: Effect of $C_{b}$ at different $Z_{b}$ values

Figures 7,8 and 9 show the effect of the change of bulk concentrations of oxygen on the percent of the aerobic one of the total floc (known as the percentage aerobic ratio). Figure 7 shows that the percentage aerobic ratio increases as the bulk concentration of oxygen increases but it decreases as the bulk concentration of substrate increases from 60 to $1200 \mathrm{mg}$ $1^{-1}$ because a substrate works as an electron donor. Figure 8 shows the effect of the change of bulk concentration of oxygen at different ammonia bulk concentrations. 
Am. J. Environ. Sci., 5 (1): 69-79, 2009

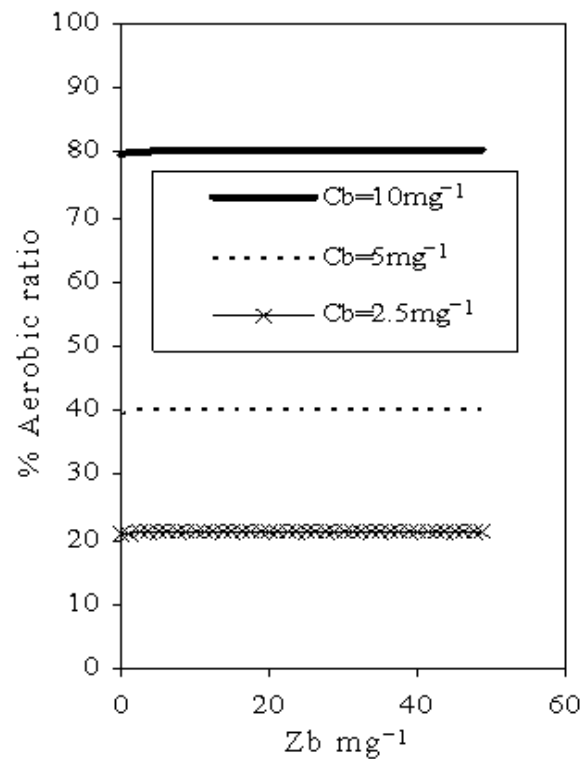

Fig. 10: Effect of $Z_{b}$ on aerobic ratio at different $C_{b}$ values

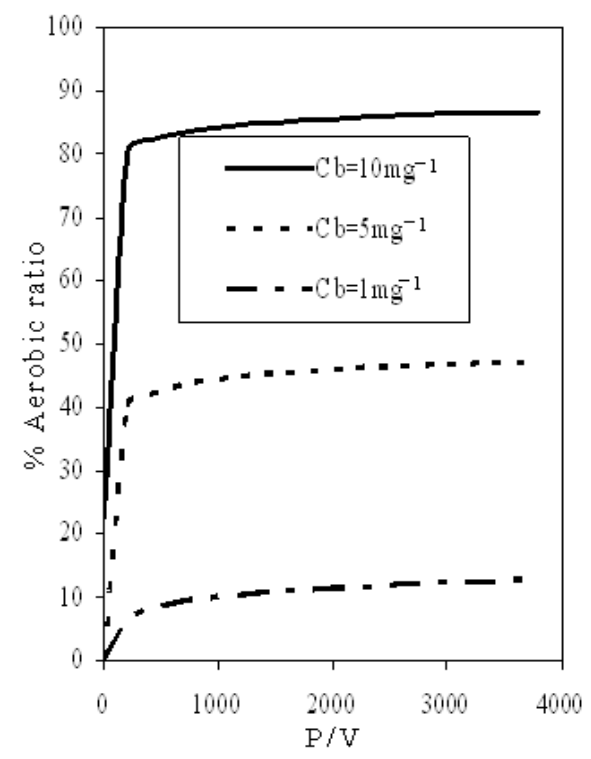

Fig. 11: Effect of power input on aerobic ratio at different $Z_{\mathrm{b}}$ values

Figure 9 shows the effect of $C_{b}$ at different $Z_{b}$. It is shown that the percentage aerobic ratio will not change as $Z_{\mathrm{b}}$ increases from 1 to $35 \mathrm{mg} \mathrm{l}^{-1}$. Figure 10 shows the response of the aerobic zone due to change in $\mathrm{Z}_{\mathrm{b}}$. As expected, the percentage aerobic ratio has not changed effectively due to the change of $\left(\mathrm{Z}_{\mathrm{b}}\right)$. Figure 11 shows the effect of the power input (energy) on the percentage aerobic ratio at different oxygen bulk concentrations

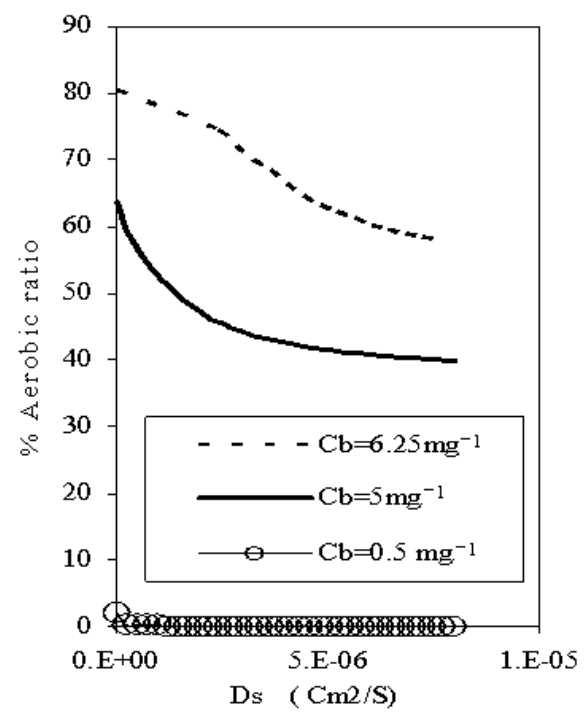

Fig. 12: Effect of substrate diffusivity on aerobic ratio at different $\mathrm{C}_{\mathrm{b}}$ values

It is clear that the percentage aerobic ratio increases sharply when the power input increases more than 200 $\mathrm{W} \mathrm{m}-^{3}$. Then as the power input is larger than 200 $\mathrm{W} / \mathrm{m}^{3}$, the percentage aerobic increases very slightly, and then it becomes stable. Furthermore, Fig. 11 shows that the percentage aerobic ratio increases when oxygen bulk concentrations increases from 1 to $10 \mathrm{mg}^{-1}$. Figure 12 shows the effect of substrate diffusivity on the percentage aerobic ratio at different bulk concentrations of oxygen $\left(C_{b}\right)$. At $C_{b}=5$ and $6.75 \mathrm{mg}^{-1}$, the percentage aerobic ratio seems to be large like 63.8 and $79 \%$ respectively for very small values of (Ds), then it decreases as (Ds) increases.

\section{DISCUSSION}

The percentage aerobic portion decreases when the floc size increases due to exhibition of aerobically inactive zone in the floc (Fig. 2). The horizontal line (AB) which is close to the center of the floc and represents $100 \%$ aerobic ratio confirms the assumption that the concentration of dissolved oxygen is identical within the bacterial colonies whereas the central bacteria in the colony may be subjected to even higher dissolved oxygen deficits due to the diffusional resistances within the bacterial colony. The decrease of the percentage aerobic ratio in the part (BC) as the increase of the floc size is due to exhibition of aerobically inactive zones in the floc. The part (BC) of the figure predicts a hyperbolic decrease in the percentage aerobic ratio due to the dissolved oxygen 
deficits as one moves away from the center of the floc. When the bulk concentrations change, the curve had the same shape but the part ( $\mathrm{AB}$ ) may be shifted to the right or the left according to the available bulk conditions. This figure is similar to that obtained by Smith P. G. and Coakley ${ }^{[16]}$ who studied the predicted oxygen deficits in a $40 \mu \mathrm{m}$ diameter floc. In the case of BOD removal, it is well known that the concentration gradient in the flocs permits more efficient substrate utilization. A similar phenomenon appears to operate for ammonia. In Fig. 3, 4, 5 and 6, oxygen works as the electron acceptor in the aerobic portion and substrates and ammonia work as an electron donor, however in the anoxic portion, the denitrification reactions occurs where the DO concentration is at low levels, so that nitrate nitrogen plays the role of an electron acceptor and ammonia works as an electron donor. In Fig. 3, the DO at the center of the floc represents $50 \%$ of that at the surface, so that the floc appears as totally active aerobic. However; the DO in Figure is consumed through the aerobic portion existing in the range 0.8-1 of the floc interior. The percent of the internal nitrate concentration increases due to oxidation of ammonia by autotrophs, where the ammonia bulk concentration exists in great amounts. Then the anoxic or denitrification portion initiates where nitrate works as a terminal electron acceptor instead of oxygen producing nitrogenous compounds and nitrous compounds

In Fig. 5, the floc is totally active which is aerobic and anoxic where nitrate is produced as a result of oxidizing of the internal ammonia by autotrophic bacteria and anoxic where nitrate is working as electron acceptor. However, the biofloc in Fig. 6 is partially active where both of the oxygen and nitrates are consumed completely before reaching the center. Our resuts agree with that obtained experimentally by Suwa et $a l .{ }^{[23]}$ who showed that the denitrification reactions occur when the DO concentration is at low levels in the interior portion of the flocs.

The percentage aerobic ratio increases with increasing of oxygen bulk concentration and it decreases with increasing substrate and ammonia bulk concentrations (Fig. 7, 8 and 9). This is because oxygen works as an electron acceptor and both substrates and ammonia as electron donors. The results in Fig. 7, 8 and 9 agree with the results obtained by Muller et al. ${ }^{[20]}$ who showed that the oxygen transfer rate became low at high substrate and ammonium concentration. Further more, this compatible with the results obtained by Smith $^{[21]}$ who showed that the stabilization rate of substrates is proportional to the dissolved oxygen concentration. Furthermore our results agree with
Baillod and Boyle (1970) ${ }^{[22]}$ who showed that substrate uptake decreased through a dissolved oxygen concentration range between 4-5 mg. $\mathrm{l}^{-1}$ for the flocculated sludge, yet the critical oxygen level dropped to 1-2 $\mathrm{mgl}^{-1}$ for the blended sludge. Ammonia behavior in Fig. 8 is similar to the behavior of substrate shown in Fig. 6, but autotrophic bacteria consumed ammonia (Fig. 8) and heterotrophic bacteria consumed the substrate (Fig. 6).

In Fig. 9 and 10, the nitrates bulk concentration has no effect on the substrates or ammonia or the oxygen concentration inside the aerobic zone. This is because the bioflocs are enriched with the bulk concentration of oxygen. Its effect exists in the anoxic zone only as an electron acceptor. These results are in agreement with M. Kornaros and G Lyberatos ${ }^{[17]}$ who showed that nitrate and nitrite concentrations remained almost constant throughout the aerobic growth and the cell growth rate did not seem to increase significantly (aerobic lag phase), while nitrate and nitrite reducing activity ceased immediately after the exposure to high dissolved oxygen concentrations.

The percentage aerobic ratio in Fig. 11 increases because the increase of the power input leads to increase of the mass transfer coefficient of oxygen rather than other components. Then when the transfer rate of oxygen is saturated the percentage aerobic increases very slightly and becomes stable. However, the percentage aerobic ratio in Fig. 12 decreases when substrate diffusivity increases because more oxygen is consumed inside the aerobic shell and when the oxygen bulk concentration is not enough the percentage aerobic ratio will be very low and seems to be unchanged.

\section{CONCLUSION}

In this study, a mathematical model was developed for activated sludge floc. The model takes into account three growth processes: \{carbonaceous oxidation, nitrification and denitrification $\}$ and four components \{substrate, ammonia, nitrate and oxygen\}. The model accounts for the internal and external mass transfer limitations and relates the external mass transfer resistance with power input. The model is able to describe the effect of liquid bulk concentrations on biofloc characteristics in terms of aerobic weight to the total floc defined as the percentage aerobic ratio. The model was used to study the effect of diffusivity of different substrates was studied. It was found that the percentage aerobic portion increases with increasing with oxygen bulk concentration and power input. 
The percentage aerobic portion decreases when the bulk concentration of ammonia and substrate increases. Both will compete to consume the internal oxygen by autotrophic and heterotrophic bacteria through aerobic growth processes.

The percentage aerobic portion was found to be unchanged due to an increase in nitrate bulk concentration. This is compatible with the experimental study by Kornaros et al. ${ }^{[17]}$; Azimi and Horan ${ }^{[18]}$. It was found also that the percentage aerobic ratio increases with increasing substrate diffusivity. The biofloc activity was studied through the profiles of the above four components. It might be totally active or partially active. The totally active biofloc is either totally aerobic or aerobic and anoxic together. In aerobic activity of the biofloc, the nitrate production was initiated due to the autotrophic reactions of ammonia but in the anoxic activity, the nitrate was consumed due to the denitrification reactions.

Finally, the aerobic portion was found to be more sensitive to changes of bulk concentrations of oxygen, substrate and ammonia in addition to the power input and substrate diffusivity and less sensitive to changes in nitrate bulk concentration.

\section{REFERENCES}

1. Tyagi, R.D., Y.G. Du and Bhamidimarri, 1996. Dynamic behavior of the activated sludge under shock loading: Application of the floc model. Water Research, 30: 1605-616. DOI: 10.1016/0043-1354(96)00045-0.

2. Hanel K. L. 1988, Biological Treatment of Sewage by the Activated Sludge Process. Ellis Chichester. Ellis Horwood Ltd., England, pp: 102133. ISBN: 9780130842862.

3. Clifft, R.C. and J.F. Andrews, 1981. Predicting the dynamics of oxygen utilization in the activated sludge process. JWPCF, 53: 1219-1232.

4. Henze, M., Grady Jr, L., W. Gujer, G.V.R. Marais and T. Matsou, 1987. A general model for single sludge wastewater treatment systems. Water Research, 21: 505-515. DOI: 10.1016/00431354(87)90058-3.

5. Lessard, P. and M.B. Beck, 1993. Dynamic modeling of the activated sludge process: A case study. Water Res., 27: 963-978. DOI: 10.1016/0043-1354(93)90060-U .

6. Ibrahim, G. and A.E. Aba Saeed, 1995. Modeling of sequencing batch reactors. Water Res., 29: 17611766. DOI: 10.1016/0043-1354(94)00317-Z.
7. Andrew, G.F., 1991. Aerobic Wastewater Process Models. In: Biotechnology, 2nd Edn., Rehm, H.J. and G. Reed, in cooperation with A. Pulher and P. Stadler, (Eds.). VCH Publisher, New York, pp: 408-439.

8. Haas, C.N., 1981. Biological process diffusional limitations. J. Environ. Eng., ASCF., 107: 269273. http:// cedb.asce.org/cgi/WWWdisplay.cgi?2160071.

9. Benefield L. and Molz F. 1983. A kinetic model for activated sludge process which considers diffusion and reaction in the microbial floc. Biotechnol. Bioeng., 25: 2591-2615. DOI: 10.1002/bit.260251109.

10. Bakti N. A. K. and Dick R. I. 1992. A model for nitrifying suspended-growth reactor incorporating intraparticle diffusional limitation. Wat. Res. 26, 1681-1690. DOI: 10.1016/0043-1354(92)90168-4.

11. Benefield, L. and F. Molz, 1984. A model for the activated sludge process which considers wastewater characteristics, floc behavior, and microbial population. Biotechnol. Bioeng., 26: 352-361. http://www3.interscience. wiley.com/journal/107620746/abstract.

12. Beccari M. Pinto A. C Di, Ramadori R. and Tomei M. C. 1992. Effects of dissolved oxygen and diffusion resistances on nitrification kinetics. Water Res., 26: 1099-1104. DOI: 10.1016/00431354(92)90146-U.

13. Atkinson B, Howell, J. A.1976, Influence of oxygen and substrate concentrations on the ideal film thickness and the maximum overall substrate uptake rate in microbial film fermenters. Biotechnol. Bioeng., 18: 15-35. DOI: 10.1002/bit.260180103.

14. John, C. Kissel, 1986. Modeling mass transfer in biological wastewater treatment processes. Wat. Sci. $\quad$ Tech., 18: 35-45. http://cat.inist.fr/?aModele $=$ afficheN\&cpsidt $=7981$ 253.

15. Moo-Young, M. and N.W. Blanch, 1981. Design of biochemical reactors: Mass transfer criteria for simple and complex systems. Adv. Biochem. Eng., 19: 1-69. DOI: 10.1007/3-540-10464-X.

16. Smith, P.G. and P. Coakley, 1983. Diffusivity, tortuosity and pore structure of activated sludge. Water Res., 18: 117-122. DOI: 10.1016/00431354(84)90056-3.

17. Kornanros, M. and G. Lyberatos, 1998. Kinetic modeling of Psedomonas denitrificans growth and denitrification under aerobic, anoxic and transient operating condition. Water Res., 32: 1912-1922. DOI: 10.1016/s0043-1354(97)00403-x. 
18. Azimi , A.A. and N.J. Horan, 1991. The influence of reactor mixing characteristics on the rate of nitrification in the activated sludge process. Water Res., 25: 419-423. DOI: 10.1016/00431354(91)90078-5.

19. Mike, K.H. and J. Hao Oliver, 1990.Comparison of activated sludge stabilization under aerobic or anoxic conditions. Res. J. WPCF., $\quad 62:$ 160-168. http://md1.csa.com/partners/viewrecord.php?reque ster $=$ gs \&collection $=E N V \&$ recid $=2826705 \& q=\& u i$ $\mathrm{d}=\&$ setcookie $=$ yes.

20. Muller, E.B., A.H. Stouthamer, H.W. Van Verseveld and D.H. Eikelboom, 1995. Aerobic domestic wastewater treatment in a pilot plant with complete sludge retention by cross-flow filtration. Water Res., 29: 1179-1189. DOI: 10.1016/00431354(94)00267-b.
21. Smith, P.G., 1984. A model of localised oxygen sinks around bacterial colonies within activated sludge. Water Res., 18: 1045-1051. DOI: 10.1016/0043-1354(84)90257-4.

22. Baillod C. R. and W.C. Boyle, 1970. Mass transfer limitations in substrate removal. J. Sanit. Eng. Div., 96: 525-545.

http://cedb.asce.org/cgi/WWWdisplay.cgi?700093

23. Suwa, Y., Yamagishi, T., Urushigawa, Y. and Hirai, M. 1989. Simultaneous organic carbon removal-nitrification by an activated sludge process with cross-flow filtration, J. Fermentation Bioeng., 67: 119-125. DOI: $\quad$ 10.1016/0922338X(89)90192-X. 